УДК 343.62:343.85

DOI https://doi.org/10.32838/TNU-2707-0581/2020.3/33

\title{
Тичина Д.М.
}

Національна академія внутрішніх справ

Посудевський I.В.

Національна академія внутрішніх справ

\section{ВІКТИМІЗАЦІЯ СІМЕЙНО-ПОБУТОВИХ ВІДНОСИН В УКРАЇНІ}

\begin{abstract}
Устаттінадано кримінологічнухарактеристику сімейно-побутовим відносинам та визначено, що ия сфера суспільних відносин перебуває у кризовому стані. Шляхом аналізу кількісноякісних показників встановлено, що домашне насильство в Україні характеризусться особливостями, які істотно відрізняються від загальної злочинності, що доводить необхідність розроблення спеціальних заходів запобіжного впливу на цей вид злочинності. Запропоновані загальні та спеціальні заходи запобігання віктимізачії сімейно-побутових відносин у кожному конкретному випадку на основі типової моделі індивідуального кримінологічного прогнозування шляхом прогностичної моделі, щяо враховує широкий спектр особистісних якостей i властивостей особи, яка об'єктивно потребує запобіжного впливу, $і$ на їх підставі визначені конкретні кримінологічні заходи індивідуального запобігання. Визначено, щзо до осіб, які потребують профілактичної корекиії, можна віднести тих, хто: негативно ставиться до сім'ї, родичів і близьких, схильний до розпусти; зловживає спиртними напоями; вживає наркотичні чи психотропні речовини; вчинив аморальні проступки в побуті, на роботі, часто створює конфліктні ситуачії, відрізняється психофізіологічною неврівноваженістю, страждає хронічними захворюваннями тощо. 3'ясовано, що поняття $і$ зміст тактики індивідуального запобігання злочинам у сфері сімейно-побутових відносин може змінюватися залежно від обсягу иіієї діяльності. У широкому розумінні вона розглядається як запобіжнна діяльність стосовно конкретної особи незалежно від стадій розвитку злочинного наміру, виникнення наміру на скоєння злочину, готування чи замах на нього. Зроблено висновок, що у кожній конкретній ситуачї пріоритет одного із віктимологічних факторів визначає симбіоз особистісних і поведінкових ознак, що характеризують жертву домашнього насильства. Водночас їх виокремлення й оцінка мають не тільки велике значення для кваліфікачії вчиненого та визначення міри покарання винного, а й для вжсиття заходів загального та індивідуального запобігання, щоб зрештою знизити зростання рівня домашнього насильства в Україні.
\end{abstract}

Ключові слова: жертва, віктимізачія, домамне насильство, сім'я, віктимна поведінка, заходи запобігання, поліиія.

Актуальність теми. Прискорення процесів європейської інтеграції України потребує впровадження у правоохоронну практику не лише сучасних форм і методів протидії злочинності, а й визнаних світовим співтовариством стандартів захисту прав і свобод людини. Реальні демократичні перетворення є невід'ємними від гуманізації соціальних відносин, адже людина, іiі життя і здоров'я, честь та гідність, недоторканність і безпека визнаються найвищою соціальною цінністю.

Виклад основного матеріалу. На розвиток українського суспільства початку XXI ст. впливають декілька груп чинників, зокрема: наслідки демонтажу соціалістичної моделі розвитку краіни (зростання соціальної незахищеності, втрата ціннісних орієнтирів, різке зниження рівня життя, збільшення маргінальної маси за рахунок безро- бітних, бездомних та інших категорій населення, які перебувають за межею бідності); складна соціально-політична ситуація (військові дії у східних областях, покращення технічної оснащеності злочинців, зростання рівня нетерпимості, девальвація морально-правових цінностей); вплив тенденцій глобалізованого світу (аномізація суспільства на рівні глибинних параметрів існування та відтворення соціуму; посилення міграційних процесів та позицій транснаціональної організованої злочинності), що в комплексі створюють підгрунтя для виникнення нових типів кримінальних загроз для населення i, відповідно, сприяють його інтенсивній віктимізації.

Загалом, проблема домашнього насильства в Україні завжди була і залишається однією із найзлободенніших. Політичні та соціально-еко- 
номічні процеси, які відбуваються в суспільстві, зокрема збройний конфлікт на Сході країни, безробіття, збільшення життєвих конфліктних ситуацій, прояви агресії в родині, болісно вражають сім'ї та призводять до зростання вчинення кривдниками домашнього насильства. А тому, визнаючи сім'ю осередком суспільства, необхідно зазначити, що без підтримки держави та їі інституцій, на жаль, проблему домашнього насильства вирішити майже неможливо. I пов'язано це 3 тим, що сім'я не завжди спроможна виконувати свою головну функцію - забезпечення належного добробуту та виховання дітей. Історія свідчить про те, що основними видами домашнього насильства $€$ : економічне, психологічне, сексуальне та фізичне насильство.

Жертва злочину (потерпілий) є істотним елементом у процесах скоєння злочину. У 1941 р. німецький кримінолог Ганс фон Гентіг відзначив існування зв'язку між злочинцем і жертвою (наприклад, взаємодія між шахраєм й обдуреним). Він виділив частину злочинності як «...процес, в якому антигромадські елементи пожирають один одного». Таким чином, дві сфери (злочинність і жертва) стають самостійними і пов'язані одна 3 одною, тобто потерпілий і злочинець протиставляються залежно від обставин, що виникають у суб'єктивно-об' єктивних відносинах [1, с. 41].

Як свідчить вивчення наукової літератури, більшість учених-лінгвістів поділяють думку про те, що етимологія слова «жертва» походить від латинського "victima", що спочатку мала культове, ритуальне значення [2, с. 74-75]. Так, у словнику Ф. Брокгауза поняття «жертва» пояснюється таким чином: «Жертва - вдячне підношення Богу від плодів земних або з царства тварин» [3, с. 22]. У Великому тлумачному словнику сучасної української мови цей термін тлумачать як «... той, хто постраждав від нещасного випадку або агресії; той, з кого знущаються, виявляють насилля; той, хто переживає, терпить різні неприємності від кого-, чого-небудь» [4, с. 274]. Д.В. Рівман наводить дві позиції щодо розуміння поняття «жертва» у віктимологічному значенні. Перша - це людина (спільність людей), якій прямо чи побічно заподіяно шкоду злочином. Друга - це фізична особа, людина, якій безпосередньо заподіяно фізичну, моральну і матеріальну шкоду [5, с. 39]. Своєю чергою В.I. Полубинський зазначає, що поняття «жертва» означає людину, яка постраждала від: а) неправомірних дій інших осіб; б) власної поведінки; в) збігу негативних обставин; г) нещасного випадку. Жертвою у вузькому сенсі слід вважати людину, якій завдано фізичну, моральну або майнову шкоду внаслідок дій інших осіб, власної поведінки, подій чи нещасних випадків [6, с. 11]. В.Є. Христенко, поклавши в основу принцип дихотомії і математичного обгрунтування терміна «жертва», вдало відзначає, що «жертва - це людина (сторона взаємодії), яка втратила вартісні для неї цінності внаслідок впливу на неї іншої людини (сторони взаємодії)» [7, с. 50]. В.О. Туляков на основі аналізу наукових, статусних, поведінкових, нормативно-правових основ і характеристик визначення потерпілих від злочинів стверджує, що жертвою злочину визнається будьяка фізична особа (соціальна спільнота), якій злочином заподіяно фізичний, матеріальний чи моральний збиток [8, с. 13].

Виходячи 3 вищевикладеного, під жертвою злочину пропонується розуміти особу (фізичну чи юридичну), якій унаслідок суспільно небезпечних діянь злочинця завдано фізичної, майнової, моральної шкоди (для фізичної особи) чи спричинено шкоду їі діловій репутації (юридична особа), або істотно порушено іiі основні права внаслідок дії або бездіяльності, та яка визнана такою в процесуальному порядку.

Вивчаючи особу будь-якої людини (у тому числі особу злочинця і потерпілого) як суб'єкта того чи іншого виду соціальної діяльності, слід мати на увазі, що між особою та іiі поведінкою $\epsilon$ нерозривний зв'язок.

15 травня у світі відзначається Міжнародний день сім'ї, мета якого - звернути увагу суспільства на важливість сім'ї та проблеми, які часто виникають у сім'ях [9]. Свято відзначають щорічно з 1994 року. Святкування Дня сім'ї було затверджене резолюцією про Міжнародний рік сім'ї Генеральної асамблеї ООН від 20 вересня 1993 року. Щорічно публікуються послання Генерального секретаря ООН 3 поточної теми дня сім’ї. ООН розглядає сім'ю як основу суспільства, тому, якщо не поважати права однієї сім'ї, під загрозою опиниться все суспільство. Основна мета - поглиблення розуміння питань родини, об'єднання можливостей різних країн для розв'язання всіх найсерйозніших питань, пов'язаних із сім'єю. Сім'я як основний елемент суспільства була і залишається берегинею людських цінностей, культури та історичної спадкоємності поколінь, чинником стабільності і розвитку. Завдяки сім'ї міцніє і розвивається держава, зростає добробут народу [9].

У всі часи за відношенням держави, а також за становищем родини в суспільстві судили про 
розвиток країни. Це тому, що щасливий союз сім'ї і держави - необхідна запорука процвітання і добробуту іï громадян. 3 сім'ї починається життя людини, тут відбувається формування ії як громадянина. Вона є джерелом любові, поваги, солідарності та прихильності, тим, на чому будується будь-яке цивілізоване суспільство, без чого не може існувати людина [9].

Віктимологічна характеристика злочинів, що вчиняються у сімейно-побутовій сфері, як комплексна кримінологічна проблема досліджена не досить [1, с. 316-325]. Майже повсюди зростає гендерна нерівність у сімейних відносинах і домашнє насильство.

Дуже важливим і кримінологічно значущим фактором домашнього насильства $\epsilon$ характер відносин між жертвою і кривдником та їхні сімейні зв'язки на момент вчинення домашнього насильства. Як справедливо відзначають науковці, зв'язок «кривдник-жертва» виникає як наслідок розвитку конфліктної ситуації, небажання досягти порозуміння, а тому юридичне значення зв'язку й відносин між жертвою та кривдником набувають із моменту вчинення домашнього насильства великого значення для суб'єкта запобігання.

Статистичні дані свідчать, що найчастіше потерпілими на сімейно-побутовому грунті стають дружина (співмешканка) (48,1\%), діти (16,6\%), а також батьки $(14,2 \%)$ винного [10, с. 49-51].

Тобто підвищений рівень віктимності мають члени сім'ї жіночої статі, відсоток яких серед усіх вивчених жертв внутрішньосімейних насильницьких злочинів становить 75,8\%. Пояснення такої високої віктимізації жінок у разі вчинення домашнього насильства варто шукати не у фатальній схильності всіх жінок стати жертвами, а в подвійному стандарті моралі, характері й стереотипах статевих відносин, що історично склалися у сучасному суспільстві. Такі злочини переважно вчиняються проти осіб зрілого віку (26-50 років), відсоток яких у структурі всіх жертв сімейнопобутової насильницької злочинності становить $57,8 \%$ [11, c. 142$]$.

Таким чином, від домашнього насильства (насильства у сім'ї), як правило, страждають найбільш беззахисні їі члени - жінки, діти, інваліди й особи похилого віку.

Насильницькі злочини в сім'ї вчиняються стосовно осіб з різним рівнем освіти: 2,2\% потерпілих не мали навіть початкової освіти; 8,0\% мали початкову освіту; $10,2 \%$ - неповну середню освіту; 40,9\% - повну середню загальну освіту; $21,2 \%$ - середню спеціальну освіту; $1,5 \%$ - неза- кінчену вищу освіту; 16,0\% - вищу освіту. Отже, звертає на себе увагу та обставина, що ці злочини найчастіше вчиняються стосовно членів сім’і 3 невисоким рівнем освіти [1, с. 316-317].

Щодо соціального стану осіб, які постраждали від домашнього насильства, були отримані такі дані: службовці - 22,4\%; працівники у сфері будівництва, виробництва, торгівлі й надання послуг - 9,1\%; фахівці в галузі науки, освіти, охорони здоров'я і соціального забезпечення $-8,4 \%$; підприємці - 2,1\%; пенсіонери - 18,9\%; учні професійних технічних училищ, технікумів (коледжів) тощо - 9,1\%; ніде не працювали і не навчалися $-28,6 \%$ [1, с. 317-318].

Отже, більшість (69,9\%) потерпілих мали статус службовця, пенсіонера або ж ніде не працювали і не навчалися. Природно, що низький соціальний статус потерпілих, якому, як правило, відповідає низький освітній і культурний рівень, має істотне віктимологічне значення.

Стійка антигромадська орієнтація і, відповідно, найбільш висока віктимність властива особам, які самі виявляють схильність до вчинення злочинів, особливо насильницького характеру. У момент вчинення насильницького злочину в сім'ї кожний сьомий $(17,2 \%)$ потерпілий мав певний досвід асоціальної поведінки і був відомий правоохоронним органам як правопорушник.

Більшість насильницьких злочинів у сім’ї пов'язана не з одиничним і випадковим, а із систематичним і понад міру вживанням потерпілими алкоголю. Систематичне пияцтво призводить до моральної деформації особи, послаблює або підриває соціально корисні зв'язки в різних типах мікросередовища, а також сприяє створенню конкретних життєвих ситуацій віктимогенно криміногенного характеру.

Віктимності жертв домашнього насильства значною мірою сприяла й така форма соціальної патології в їхній поведінці, як сексуальна розбещеність, відсутність морально-етичної вибірковості у сфері інтимних стосунків. Так, кожен п'ятий $(20,1 \%)$ потерпілий до вчинення проти нього насильницького злочину вів аморальний, розбещений спосіб життя.

Отже, у разі сексуальних злочинів доцільно збирати такі відомості про особу потерпілого, як: вік, стать, фізичні особливості, сімейний статус, соціальна адаптованість, інтелект, взаємини, успішність у навчальному закладі, стиль життя і недавні зміни в стилі життя, особливості особи, iï темпераменту, манера поведінки, місце проживання (попереднє й останнє), репутація вдома і на 
роботі, історія хвороби (фізичні і психічні особливості), особисті звички (вживання алкоголю, наркотиків), соціальні звички, захоплення, пристрасті, друзі й вороги тощо.

У процесі визначення цілей і завдань системи віктимологічних заходів запобігання сімейнопобутовим правопорушенням необхідно виділити iii загальносоціальний, спеціально-кримінологічний та індивідуальний рівень [12, с. 127-128].

Загальносоціальні віктимологічні заходи запобігання домашньому насильству полягають перш за все у вирішенні соціально-економічних і культурно-виховних завдань і таких, що сприяють кримінологічній віктимізації сімей, а також зниженню ступеня їх віктимності [13, с. 133].

Спеціально-кримінологічні заходи запобігання злочинам, що аналізуються, мають здійснюватися державними органами, громадськими об'єднаннями, організаціями й окремими громадянами, реалізуючи віктимні властивості та якості окремих осіб або груп населення.

Індивідуально-профілактична робота із запобігання сімейно-побутовій злочинності має бути організована за законами України з урахуванням поведінки або сукупності особистих характеристик осіб, які можуть стати жертвами злочинців, та спрямована на підвищення активності їх захисних реакцій, а також забезпечення особистої, майнової та іншої безпеки [14, с. 60-61].

До осіб, які потребують профілактичної корекціï, на наш погляд, можна віднести тих, хто:

- негативно ставиться до сім'ї, родичів і близьких, схильний до розпусти;

- зловживає спиртними напоями;

- вживає наркотичні чи психотропні речовини (коли це не викликано медичними потребами);

- вчинив аморальні проступки в побуті, на роботі, часто створює конфліктні ситуації, відрізняється психофізіологічною неврівноваженістю, страждає хронічними захворюваннями тощо.

Тому можна запропонувати такі шляхи вдосконалення запобіжної діяльності у досліджуваній сфері:

1) розробити науково обгрунтовану методику прогнозування можливої протиправної (у тому числі й злочинної) поведінки, що дасть змогу чітко виявляти осіб, стосовно яких є потреба негайного вжиття індивідуальних спеціальних заходів щодо запобігання злочинам;

2) відпрацювати чіткий перелік правових підстав застосування методик як прогнозування, так і подальшої реалізації запобіжних заходів i затвердити їх відповідними законодавчими та відомчими нормативними актами, розробити систему критеріїв, наявність яких передбачає застосування спеціальних профілактичних заходів стосовно конкретної особи, грунтуючись на фактичних кримінологічно виважених підставах, комплексах ознак як правових, так і психологопедагогічних тощо;

3) визначити процедуру і механізм прийняття рішень щодо застосування заходів прогнозування та їх реалізації;

4) установити субординаційний порядок та визначити варіанти і критерії узгодженості дій посадових осіб, відповідальних за цю діяльність, 3 метою уникнення порушень загальнолюдських стандартів прав людини, можливих інших помилок та настання негативних наслідків;

5) розробити методики вивчення особистісних ознак та реального мікросередовища, які слід застосувати з метою запобіжного впливу, збору, накопичення, аналізу й реалізації наявної інформації на користь цієї особи.

При цьому має бути досить висвітлені:

- соціально-демографічні ознаки (стать, вік, освіта, сімейний стан тощо);

- вольові якості (здатність протистояти негативному впливу, рішучість і наполегливість, а також прояви впертості, намагання у будь-який спосіб задовольнити власні егоїстичні інтереси, спроможність підпорядкувати своєму негативному впливу оточуючих);

- емоційні властивості (уміння спокійно й виважено поводитися у критичних ситуаціях, вияви нестриманості, дратівливості, неврівноваженості, ревнощів, надмірної сором'язливості, образливості та злопам'ятства);

- соціально корисні інтереси (ініціативність, уміння організувати дозвілля, наявність захоплень та їх характер та ін.);

- морально-психологічні ознаки, властивості та якості (темперамент, риси характеру як позитивні, так і негативні, зокрема прояви постійної невдоволеності, озлобленості, зухвалості, жадібності, цинізму, помсти, боягузтва, замкнутості, жорстокості, егоїзму, ледарства та брехливості);

- характеристика за місцем проживання (схильність до пияцтва, шкідливих звичок, факти конфліктних ситуацій із сусідами та близьким оточенням);

- сімейні стосунки (подружні відносини, байдуже, зневажливе та безвідповідальне ставлення до батьків, дітей, прояви ворожнечі в сім'ї тощо);

- антигромадські інтереси та прагнення (схильність до вживання наркотиків, пияцтва, шкідли- 
вих звичок, стійкі стосунки з особами, які мають антисуспільну (кримінальну поведінку, прояви аморальності та ін.);

- взаємодія у мікросоціальному середовищі (наявність негативного впливу дружніх зв'язків, сім'ї, близьких чи випадкових знайомих під час спільного проведення дозвілля поза місцем проживання, невжиття заходів щодо нормалізації стосунків у сім'ї, потурання протиправній, у тому числі злочинній, поведінці сімейного оточення та ін.);

- схильність до нерозбірливих зв'язків та антигромадської поведінки (зв'язок з учасниками груп антисоціальної спрямованості з корисливих мотивів, постійні конфлікти в сімейно-побутових стосунках, наявність повідомлень про порушення громадського порядку, зловживання, аморальну поведінку).

Поняття і зміст тактики індивідуального запобігання злочинам у досліджуваній сфері може змінюватися залежно від обсягу цієї діяльності. У широкому розумінні вона розглядається як запобіжна діяльність стосовно конкретної особи незалежно від стадій розвитку злочинного наміру, виникнення наміру на скоєння злочину, готування чи замах на нього.

Зокрема, широкий аспект охоплює такі стадії запобігання:

- вивчення осіб, які своєю поведінкою становлять профілактичний інтерес;

- здійснення їх поглибленого вивчення і діагностики з позиції наявності криміногенності;

- прогнозування імовірної злочинної поведінки і у разі отримання прогностичних висновків, що свідчать про можливість скоєння злочину, прийняття адекватного рішення щодо запобіжних та інших (управлінських, організаційних, кадрових) заходів;

- планування відповідно до прогнозу індивідуальних запобіжних заходів недопущення злочину;

- практична реалізація запланованих заходів і контроль за подальшою поведінкою особи;
- оцінка і висновки стосовно поведінки особи й доцільності подальшого продовження чи припинення індивідуальних запобіжних дій та щодо ефективності застосованих профілактичних засобів.

У кожному конкретному випадку на основі типової моделі індивідуального кримінологічного прогнозування має бути розроблена персональна прогностична модель, що найповніше враховуватиме широкий спектр особистісних якостей та властивостей особи, яка об'єктивно потребує профілактичного впливу, і на їх підставі визначені конкретні тактичні заходи індивідуального кримінологічного запобігання.

Тобто основним завданням віктимологічного запобігання сімейно-побутовій злочинності (домашнього насильства) $є$ створення системи ефективного соціального захисту всіх громадян від можливої віктимізації [15, с. 205-206], зміна сформованої практики поведінки з потерпілими та іншими жертвами злочинів. Для цього необхідно розробити або удосконалити чинне законодавство, створити нові державні та недержавні структурні підрозділи, соціальні служби, фонди допомоги жертвам, реабілітаційні центри та інші організації із захисту жертв злочинів, організувати підготовку спеціалістів для такої роботи.

Висновки. Таким чином, у кожній конкретній ситуації пріоритет одного із віктимологічних факторів визначає симбіоз особистісних і поведінкових ознак, що характеризують жертву домашнього насильства. Водночас їх виокремлення й оцінка мають не тільки велике значення для кваліфікації вчиненого та визначення міри покарання винного, a й для вжиття заходів загального та індивідуального запобігання, щоб зрештою знизити зростання рівня домашнього насильства в Україні. Практика та закордонні дослідження показали, що 64\% людей, які стали жертвами домашнього насильства, надалі самі стають кривдниками, i, навпаки, ті, хто змолоду не став жертвою домашнього насильства, стають у три рази (на $22 \%$ ) рідше.

\section{Список літератури:}

1. Кримінологічна віктимологія : навчальний посібник / Є.М. Моісеєв, О.М. Джужа, В.В. Василевич та ін. ; за заг. ред. О.М. Джужі. Київ : Київ. нац. ун-т внутр. справ, 2006. 416 с.

2. Джужа О.М., Моісеєв С.М. Жертва злочину: підходи до визначення та проблеми класифікації. Вісник Луганського держ. ун-ту внутр. справ. ім. Е.О. Дідоренка. 2011. № 2. С. 74-81.

3. Энциклопедический словарь Ф.А. Брокгауза и И.А. Ефрона: у 86 т. Москва, 1996. Т. 11. 942 с.

4. Великий тлумачний словник сучасної української мови / уклад. і голов. ред. В.Т. Бусел. Київ; Ірпінь : Перун, 2001. 1736 с.

5. Ривман Д.В. Криминальная виктимология : учебник. Санкт-Петербург : Питер, 2002. 304 с.

6. Полубинский В.И. Правовые основы учения о жертве преступления : учебное пособие. Горький : Горьк. высш. шк. МВД СССР, 1979. 83 с. 
7. Христенко В.Е. Психология поведения жертвы : монография. Ростов-на-Дону : Феникс, 2004. 416 с.

8. Туляков В.О. Вчення про жертву злочину: соціально-правові основи : автореф. дис. ... докт. юрид. наук : 12.00 .08 «Кримінальне право та кримінологія; кримінально-виконавче право». Одеса, 2001. 37 с.

9. Міжнародний день сім'ї: матеріал з Вікіпедї̈ - вільної енциклопедіï. URL: https://uk.wikipedia.org/ wiki/ Міжнародний день сім\%27ї.

10. Navies P., Francis P. Jupp V. Victimisation: Theory, Research and Policy. New York, 2008. P. 49-51.

11. Методика кримінологічного дослідження злочинності в Україні : монографія / О.М. Джужа, О.Г. Кулик, В.В. Василевич та ін. ; за заг. ред. О.М. Джужі. Київ : Київ. нац. ун-т внутр. справ, 2006. 192 с.

12. Українська кримінологічна енциклопедія : наукове видання / за заг. ред. В.В. Чернєя, В.В. Сокуренка ; упоряд. О.М. Джужа, О.М. Літвінов. Харків-Київ : Харк. нац. ун-т внутр. справ; Нац. акад. внутр. справ; Кримінолог. асоц. України; Золота миля. 2017. 804 с.

13. Кримінологія : підручник / О.М. Джужа, В.В. Василевич, В.В. Чернєй, С.С. Чернявський та ін. ; за заг. ред. д-ра юрид. наук, проф. В.В. Чернєя; за наук. ред. д-ра юрид. наук, проф. О.М. Джужі. Київ : ФОП Маслаков, 2020. 612 c.

14. Велика українська юридична енциклопедія: у 20 т. Т. 18: Кримінологія. Кримінально-виконавче право / редкол.: В.І. Шакун, В.І. Тимошенко та ін. Харків : Право, 2019. 544 с.

15. Джужа О.М. Запобігання злочинам: кримінолого-віктимологічна парадигма : монографія. Київ : Нац. акад. внутр. справ, 2015. $331 \mathrm{c.}$

\section{Tychyna D.M., Posudevskyi I.V. VICTIMIZATION OF FAMILY AND DOMESTIC RELATIONS IN UKRAINE}

The article provides a criminological description of family and domestic relations and determines that this area of public relations is in crisis. By analyzing quantitative and qualitative indicators, it was found that domestic violence in Ukraine is characterized by features that differ significantly from general crime, which proves the need to develop special measures to prevent this type of crime. The general and special measures of prevention of victimization of family and household relations in each case are offered on the basis of a typical model of individual criminological forecasting by means of the prognostic model taking into account a wide range of personal qualities and properties of the person objectively in need of preventive influence, criminological measures of individual prevention. It is determined that in relation to persons in need of preventive correction, we can include those who: have a negative attitude towards family, relatives and friends, are prone to fornication; abuses alcohol; uses narcotic or psychotropic substances; committed immoral offenses in everyday life, at work, often creates conflict situations, has psychophysiological imbalance, suffers from chronic diseases and more. It was found that the concept and content of tactics for individual prevention of crimes in the field of family and domestic relations may vary depending on the scope of this activity. In a broad sense, it is considered as a preventive activity against a particular person, regardless of the stages of development of criminal intent, the emergence of intent to commit a crime, preparation or attempt to commit it. It is concluded that in each case the priority of one of the victimological factors determines the symbiosis of personal and behavioral characteristics that characterize the victim of domestic violence. At the same time, their isolation and evaluation are important not only for the qualification of the perpetrator and the punishment of the perpetrator, but also for the adoption of general and individual prevention measures to ultimately reduce the growth of domestic violence in Ukraine.

Key words: victim, victimization, domestic violence, family, victim behavior, prevention measures, police. 